\title{
THE INFLUENCE OF JOB EXPECTATION, JOB SATISFACTION, AND GOVERNMENT POLICY TOWARDS THE WORK STRESS, JOB ENTHUSIASM AND CONTINUANCE COMMITMENT OF THE HONORARIUM TEACHER
}

\author{
Tuty Sariwulan $^{1^{*}}$, Iskandar Agung ${ }^{2}$, Unggul Sudrajat $^{3}$, Genardi Atmadiredja ${ }^{4}$ \\ ${ }^{1}$ State University of Jakarta, Indonesia, ${ }^{2,3,4}$ Center of Research Policy Education and Culture, MOEC, \\ Republic of Indonesia \\ *e-mail: tuty.wulan@unj.ac.id
}

\begin{abstract}
This study aims to determine the effect of job expectations (JE), job satisfaction (JS), and government policy (PG) on work stress (WS), work passion (JEn), and continuance commitment (CC) to honorarium teachers in middle and high school. Data collection was done through questionnaires and analyzed using the SEM approach with the help of the Lisrel 8.80 program. The results of the analysis show that the variables JE, JS, and PG have an influence on WS; and WS has an influence on JEn and CC. Explicitly, the conditions and situations faced by honorary teachers tend to create a desire to find new workplaces. This was also reinforced by the issuance of Government Regulation No. $49 / 2019$ concerning the acceptance of workers with work agreements and prohibits the existence of honorarium status. It is recommended, it is necessary to give priority to honorary teachers by not using work contracts, but by treating them for a certain period of time, then being appointed as permanent (non-ASN) teachers if they are judged to meet their requirements and eligibility.
\end{abstract}

Keywords: job expectation, job satisfaction, government policy, work stress, job enthusiasm, continuance commitment

\section{PENGARUH HARAPAN KERJA, KEPUASAN KERJA, DAN KEBIJAKAN PEMERINTAH TERHADAP STRES KERJA, ANTUSIASME KERJA, DAN KOMITMEN KEBERLANJUTAN PADA GURU HONORARIUM}

\begin{abstract}
Abstrak: Studi ini bertujuan untuk mengetahui pengaruh harapan kerja (JE), kepuasan kerja (JS), dan kebijakan pemerintah (PG) terhadap stres kerja (WS), antusiasme kerja (JEn), dan komitmen berkelanjutan (CC) guru honorarium di SMP dan SMA. Pengumpulan data dilakukan melalui kuesioner dan dianalisis menggunakan pendekatan SEM dengan bantuan program Lisrel 8.80. Hasil analisis menunjukkan bahwa variabel JE, JS, dan PG memiliki pengaruh terhadap WS; dan WS memiliki pengaruh pada JEn dan CC. Eksplisit, kondisi dan situasi yang dihadapi oleh guru honorer cenderung memunculkan keinginan untuk mencari tempat kerja baru. Hal itu juga diperkuat dengan dikeluarkannya Peraturan Pemerintah No. 49/2019 tentang penerimaan pekerja dengan perjanjian kerja dan melarang adanya status honorarium. Direkomendasikan, perlu memberikan prioritas penerimaan kepada guru honorer dengan tidak menggunakan perjanjian kerja (kontrak), melainkan dengan perlakuan percobaan selama waktu tertentu, kemudian diangkat sebagai guru tetap (non-ASN) apabila dinilai memenuhi persyaratan dan kelayakannya.
\end{abstract}

Kata Kunci: harapan kerja, kepuasan kerja, kebijakan pemerintah, stres kerja, gairah kerja, komitmen berkelanjutan

\section{INTRODUCTION}

The phenomenon of honorary teacher appointments has emerged since some of the reasons are the large number of teachers entering retirement age. Although Law No. 14/2005 on Lecturers and Teachers has extended the working period of teachers to the age of 60 years, in fact many regions in Indonesia face the problem of teachers entering retirement age. Many areas lack teachers and try to overcome them. In urban areas to overcome this phenomenon, teachers are required to teach in two schools. Another way to deal with this problem is by conducting honorary teacher appointments by the school. 
In a meeting with the House of Representatives(DPR), the Minister of Education and Culture said that, in 2018, the number of retired teachers reached 295,779 people. Due to the lack of teaching staff, many schools eventually appointed teaching staff with honorary and nonpermanent status. Most of these teachers are graduates of educational and non-educational study programs. The main reason for becoming an honorary teacher is the desire to be appointed as a civil servant. They are willing to wait, even though there was a recruitment moratorium a few years ago; and only reopened in a relatively small number of teachers two years ago. In addition, honorary teachers are also willing to be paid very unsatisfactorily to fulfill their daily lives.

One way to overcome the problem of teacher shortages, especially honorary teachers, Government Regulation (PP) Number 49/2018 was issued regarding Management of Government Employees with Employment Agreements (PPPK). The implication is that the government will have two types of employee status, namely: State Civil Apparatus and government employees with work agreements (Article 2). In Law No. 49/2018, honorary teachers are no longer permitted. Schools may not appoint honorary teachers whose fees are taken from the Special Allocation Fund from the government. The President of the Republic of Indonesia explicitly said, with the first aid scheme, all central and regional institutions in any form could not appoint honorary employees. Procurement of PPPK candidates is carried out by government institutions through objective assessments based on competence, qualifications, institutional requirements, and other requirements needed.

What about honorary teachers at school? Do they have to resign through the application of Law No. 49/2018. This means that they must register and take part in the selection to become teachers with work agreements. This will bring psychological pressure to honorary teachers because of undervalued work experience, and uncertainty to be accepted as first aid teacher. Application of agreements will result in job stress for honorary teachers, thus disrupting work concentration due to uncertainty in status. The latter is the reason for conducting a study of honorary teachers. The phenomenon on this basis it is necessary to study the phenomenon of honorary teachers because of a tendency to resign. Uncertainty is reinforced by regulations that are considered to be less supportive of their desire to become permanent teachers, on the contrary only offer with work agreements. If the resignation of honorary teachers occurs, it is estimated that it will have a negative impact on schools and students. Through this research, we want to know how the influence of work expectation factors, job satisfaction, and government policies on work stress, enthusiasm and commitment to continue working as honorary teachers. The results of the study are expected to provide conclusions to determine alternatives to overcome the problem of honorary teachers. Next below is explained the understanding of each variable studied.

\section{Honorarium teachers}

In simple terms the teacher can be interpreted as someone who helps others to gain knowledge, competence or values. Suparlan (2018) argues that teachers can be interpreted as people whose duties are related to efforts to educate the nation's life in all aspects, both spiritual and emotional, intellectual, physical, and others. Mulyasa (2006) calls it a learning agent. In the Indonesian context the understanding of teachers is stated in Law No. 14/2005 concerning Lecturers and Teachers, as professional educators with the main task of educating, teaching, guiding, directing, training, evaluating and evaluating students in early childhood education through formal primary and secondary education institutions.

There are two types of teacher status, namely Permanent Teachers and Non-Permanent Teachers. Permanent teachers are those who have become civil servants and are assigned to certain schools. Private schools are declared as permanent teachers if they already have the authority to teach and be accredited by the government. Non-permanent teachers are paid based on teaching hours each month, so they are often referred to as honorary teachers. Records of the Ministry of Finance of the Republic of Indonesia, honorarium or honor are defined as money given to non-permanent teachers/ lecturers or honorary employees. However, honorary teachers are generally not paid by the government but by schools with relatively low 
amounts. Schools usually only pay between Rp.25 thousand - Rp.50 thousand per hour teaching. The existence of honorary teachers in schools is usually with the aim of overcoming teacher shortages while awaiting permanent acceptance of ASN teachers.

\section{Job expectation (JE)}

Although honorarium teachers must wait long with uncertainty, they continue to teach at school. Job expectation is one of the drivers underlying the honorarium teacher being appointed as a civil servant. Vroom (1964) suggest that people would be motivated to do certain things to achieve goals. This expectation of work might explain why a person or group of people becomes the honorarium teachers, even though they know that they have relatively low income but support the workload as practiced by permanent teachers. This expectation is even greater if it is associated with the regulations in the Law No. 14/2005 which gives the teacher the right to receive basic salary if he has passed the competency test and has an educator certificate.

Various studies have shown that there is a relationship between the influence of work expectations and other aspects of work. Orpen (1974) suggests that there is a relationshipbetween job expectations and managerial performance. Greenhaus, Saidel, \& Marinis (1983) show a positive influence on job expectations on work behavior. Asnawi \& Bachroni (1999) show the influence of great expectations on work with the involvement of the task and the attitude of work discipline. Ratnasari (2015) finds that there is a positive influence between work expectations on the employee performance.

\section{Job satisfaction (JS)}

Job satisfaction is related to high and low feeling of someone about their work. Luthans (2011) argues that when someone gets job satisfaction from his work environment, he will give good performance, and vice versa. In line with that Vecchio (1995); Greenberg \& Baron (2003); Wibowo (2007) suggest that job satisfaction is a positive feeling towards the works, otherwise dissatisfaction is a response to negative feelings towards the works. Kirkpatrick \& Levis (1996) suggest that job satisfaction is a person's attitude towards his work on the elements of the nature of the work itself, relations with colleagues, compensation received, promotion opportunities, quality of supervision received and work situations.

Various studies show the effect of job satisfaction on other aspects of works. Bakan, Buyukbese, Eroahan, Sezer (2014); Shaju \& Subhashini (2017) find the effect of job satisfaction on employee performance. In Indonesia, a study conducted by Mulia (2013) also finds a relationship between the effect of job satisfaction and employee performance: the higher job satisfaction tends to be higher employee performance, and vice versa. Darmawati, Hidayati \& Dyna (2013) through her research shows the influence of job satisfaction on the citizenship behavior of employee organizations. Hidayat (2018) finds one of the effects of job satisfaction on employee turnover intentions. Werang (2014) shows that job satisfaction is one of the variables that influence teacher performance, and it is assumed that job dissatisfaction will have a negative impact in the form of work pressure.

\section{Government policy (PG)}

One of the policies issued was the application of the 2013 curriculum(K-13) through the Regulation of the Minister of Education and Culture No. 81a in 2013 replaced the 2006 curriculum. So far, the implementation of K-13 has faced various obstacles, both in terms of the availability and distribution of books, facilities and infrastructure, and the understanding of principals and teachers, mastery of information technology, etc. (Krissandi \& Rusmawan, 2013). Another obstacle found was the density of teaching materials faced and the lack of time allocation for complex teaching and learning activities and evaluation systems (Sinwan, 2014).

Implicitly, honorary teachers must also apply K-13. Ironically, not all honorary teachers know and understand teaching material on $\mathrm{K}-13$. They must work hard to understand and apply K-13 such as permanent teachers who have received K-13 training. It is assumed that honorary teachers will face certain psychological stresses related to the application of the K-13 curriculum. Noviyanti \& Erwandi (2012) found that the majority of honorary teachers studied had moderate to severe work stress caused by content factors on work. Herjany \& Bernarto 
(2018) show that work stress is experienced by workloads in schools that affect teacher organizational commitment.

Another problem is that schools are not easy to pay honorariums, because there are regulations prohibiting withdrawals from parents. From the field, it was found that schools paid teacher salaries by allocating special allocation fund programs and / or school operational assistance obtained from the government. Issuance of Government Regulation No. 49/2018, schools must dismiss honorary teachers, especially if the payment comes from special allocation funds or school operational assistance that is not to pay honorary teachers.

\section{Work stress (WS)}

Work stress is a human factor that is often experienced by employees in facing workloads. The situations of the work environment, both physical and non-physical, which are less conducive will also lead to psychological, physiological, and behavioral problems of a person or group of employees. A stuffy work environment, heat, noise, insecurity, inconvenience, or a social environment in the form of unfamiliar and empathetic social relations, leadership that tends to be rigid and authoritarian, lack of transparency in the system of improving career work and salary/wage work, etc. are examples of physical and social work conditions that are not conducive. Management and organizational experts tend to argue that work stress is the employee's response to the work environment (Kusluvan, 2003; Mullins, 2007; Luthans, 2011; Colquitt, Jeffery, \& Michael, 2015).

High or low pressure received by employees will affect patterns of work behavior. Work stress can affect the work performance and quality of employees. Jazak (2015) argues that the negative phenomenon of work stress is a decrease in motivation or de-motivation and morale; reduce performance which results in a decrease in employee contributions to the organization, reduce productivity, reduce individual competitiveness, create a work environment that is not conducive, generate losses, and so on. Rizkiyani \& Saragih (2012) find that there is a relationship between work stress and work motivation. Work stress will cause employees to be unmotivated, frustrated and reduce their performance. Sukadiyanto (2010) describes a number of characteristics of people who experience work stress, including: feeling nervous and anxious irritability, anxiety, fatigue, reluctance to do activities, decreased work ability and appearance, feeling of fear, excessive concentration, loss of spontaneity, alienation yourself from a group, and pobia. Such conditions will be followed by individuals with self-estrangement from the group, lack of confidence, and low work productivity, so that if action is not taken quickly it will lead to the emergence of depression.

\section{Job Enthusiasm (JEn)}

Job enthusiasm is an effort to do work so that it is resolved faster and better (Nitisemito, 1992). The work environment will definitely affect the employees' job enthusiasm. Certainty of employment status, promotion of career advancement, application of rewards for achievement, harmonious cooperation, etc. will drive the ethos of high employee, motivation and work behavior. Employees tend to work hard, discipline, dedication, and high responsibility for their work. On the contrary, the work environment that leads to psychological stress, uncertainty about future status and career, lack of appreciation for achievement, rigid and less harmonious working relationships, etc. will only reduce employee enthusiasm.

Various studies show that work passion influences employee performance. Handayani (2016); Bawelle \& Sepang (2016); Sjahruddin (2017) suggest that there is a positive influence between job enthusiasm on employee performance. Allegedly the same situation also occurs in the life of the honorarium teacher

\section{Continuance commitment (CC)}

Colquitt, et. al. (2015); Luthans (2011) argue that organizational commitment is a condition of how much an employee ties himself to the organization and adheres to organizational goals and hopes to maintain membership in the organization. One aspect of organizational commitments is a continuance commitment that refers to the views of employees to maintain or to leave the organization. Employees consider their work continuity to be caused by needs and other factors, such as certainty of work status, career advancement, adequate income, and so 
on. Employees continue to work in organizations because they collect more benefits that they receive. Conversely, the low strength of the continuance commitment tends to bring someone to move to another workplace.

In the context of honorary teachers, things that are not favorable above are considered to affect the continuation commitment to work in school. Quite a number of honorary teachers who resigned from school are indicative of a decline in continuing commitment. The expectation of becoming a government employee, low income, a regulation that requires selection to become an employee with a work agreement, are some aspects that affect the decline in continuance commitment. The regulation also prohibits agencies from receiving temporary employees, and even according to the Minister of Education and Culture, schools are prohibited from accepting honorary teachers (Koran Sindo, 2018).

\section{METHODS \\ Approach}

Writing is part of the results of field studies that have been conducted since October 2017 in six regions: Pekanbaru, Padang, Malang, East Lombok, Makassar, and Kendari. Location determination is more of a random sampling with three regions in the western part of Indonesia and three in the eastern part of Indonesia.

\section{Sample Respondent}

This research has been conducted since October 2017 by conducting interviews and focus group discussions (FGD) in the Education Office in six regions: Pekanbaru, Padang, Malang, East Lombok, Makassar, and Kendari). Participants in the discussion were attended by several education officials, principals, and teacher honorariums for junior and senior high school. Honorarium teachers were obtained from four schools (two junior high schools and two secondary schools). One junior and senior high school was chosen as "good" represented by three teachers teaching subjects in science, mathematics, and social sciences. One other junior and senior high school is categorized as "sufficient / moderate" which is only represented by two teachers teaching mathematics and social sciences. The total number of honorarium teachers of the participants is 10 people in each region
The sample of respondents from this study were honorary teachers from junior and senior high schools in the six study locations. Honorary teachers are obtained from four schools (two junior high schools and two secondary schools). One junior and senior high school was chosen as "good" represented by three teachers teaching subjects in science, mathematics, and social sciences. One other junior high school and high school is categorized as "moderate" which is only represented by two teachers who teach mathematics and social sciences. The total number of honorary teachers is 10 in each region. This teacher was asked to answer the questionnaire and was one of the participants in the focus group discussion.

\section{Instrument}

The main instrument used in this study was a questionnaire for teachers. The previous questionnaire was validated and verified using product moment test criteria from Pearson and Cronbach Alpha using the SPSS version 24.0 program. In addition, the study also conducted an FGD with participants from the local Education Office Officials, School Principals and teachers from the sample schools.

\section{Data collection and analysis}

Especially in distributing questionnaires, obtained from the total discussion participants there were 60 people. For the purposes of analysis, teacher samples were added with 60 honorary teacher demonstration participants in front of the palace on October 31, 2017 at random. The total sample of teachers is 120 people. Analysis of the relationship between variables is done through the Structural Equation Modeling (SEM) approach using the Lisrel 8.80 program. The use of the SEM approach can be done, because the sample meets the minimum requirements of 100 respondents (Kusnendi, 2008).

\section{Theoretical models and Hypothesis}

The theoretical model used in this study, as Figure 1.

The hypothesis proposed in this study are:

- Job Expectation (JE) has an influence on Work stress (WS)

- Job Satisfaction (JS) has an influence on Work stress (WS) 


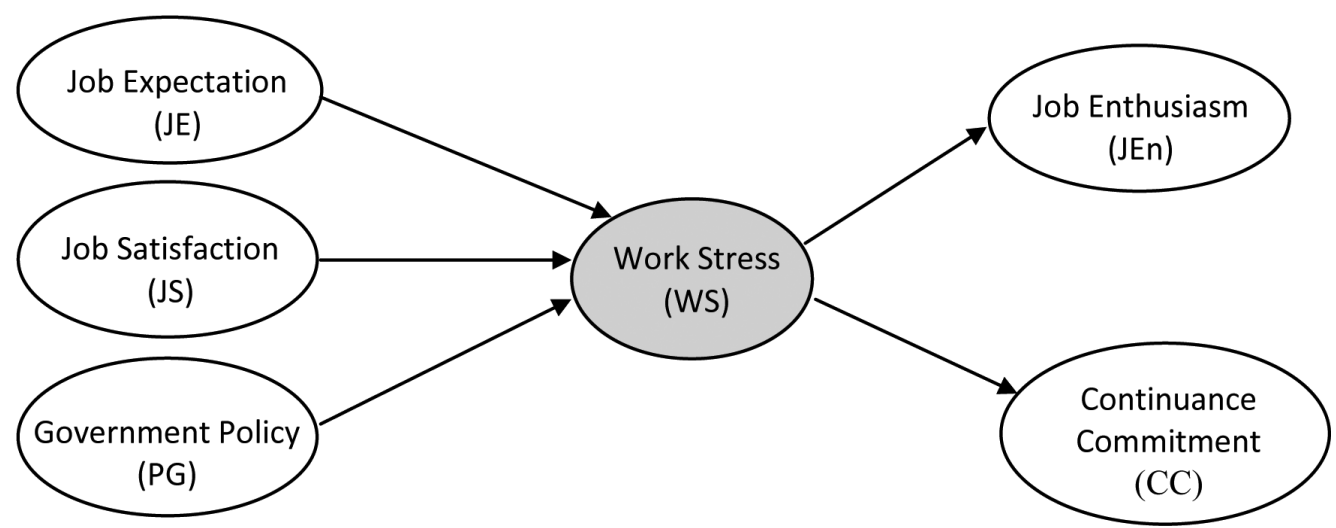

Figure 1. Theoretical Models the Influence of Job Expectation, Job Satisfaction, and Government Policy towards Work Stress, Job Enthusiasm and Continuance Commitment of the Teacher's Honorarium

Table 1. Distribution respondent of Teacher Honorarium by Teaching Place

\begin{tabular}{clccc}
\hline No. & \multicolumn{1}{c}{ District/ Municipality } & $\begin{array}{c}\text { Discussion } \\
\text { Participants (2017) }\end{array}$ & $\begin{array}{c}\text { Demo Action } \\
\text { (2018) }\end{array}$ & Total \\
\hline 1. & Pekanbaru municipality, Riau Province & 10 & - & 10 \\
2. & Padang municipality, West Sumatra Province & 10 & 2 & 12 \\
3. & Malang municipality, East Java Province & 10 & 6 & 16 \\
4. & East Lombok District, West Nusa Tenggara Province & 10 & 2 & 12 \\
5. & Makassar municipality, South Sulawesi Province & 10 & - & 10 \\
6. & Kendari municipality, Southeast Sulawesi Province & 10 & - & 10 \\
7. & Bogor District, West Java Province & - & 8 & 8 \\
8. & Bekasi District, West Java Province & - & 12 & 12 \\
9. & Purwakarta District, West Java Province & - & 4 & 4 \\
10. & Kerawang DIstrict, West Java Province & - & 3 & 3 \\
11. & Bandung District, West Java Province & - & 4 & 4 \\
11. & Serang District, Banten Province & - & 6 & 6 \\
12. & Tegal District, Central Java Province & - & 4 & 4 \\
13. & Kebumen District, Central Java Province & - & 6 \\
14. & Lampung Selatan District, Lampung Province & - & 3 \\
\hline \multicolumn{7}{r}{ Total } & $\mathbf{6 0}$ & $\mathbf{6 0}$ & $\mathbf{1 2 0}$ \\
\hline
\end{tabular}

- Government Policy (PG) has an influence on Work stress (WS)

- Work stress (WS) has an influence on Job Enthusiasm (JEn)

- Work stress (WS) has an influence on Continuance Commitment (CC)

\section{FINDINGS AND DISCUSSION Findings}

From the questionnaire processing 63 people taught in junior high schools and 57 taught in high schools. $80.83 \%$ respondents were male teachers, and $19.17 \%$ were women. Table 1 shows the distribution of respondents according to the city where they teach.

Most respondents said that they had taught more than 5 (five) years, only a few said that they had not taught more than 5 years. In addition, it was found that the wages received were calculated from the number of teaching hours. The average income received by honorary teachers is IDR 450,000; the lowest is Rp.300,000, and the highest is Rp.600,000.

From the sample it is expected to be able to represent the aspirations of honorary teachers in Indonesia, especially in public schools.

\section{Confirmatory Factors Analysis (CFA) Results Validity Results}

Latan (2012) suggests that Confirmatory Factor Analysis (CFA) is conducted to test the dimensionality of a construct or variable. CFA needs to be implemented as a test of validity and reliability to determine whether indicator 
variables really form the latent variables studied. Validity test is done to find out whether the question items meet the standardization value of the factor. If the value of the standard loading factor is greater than .5 , the question item is valid. Table 2 shows that all items in the statement or indicator in this study are valid, because they have a loading value which is greater than .5 .

Table 2. Results of Validity of CFA Teacher Study Honorarium

\begin{tabular}{cccc}
\hline Variable & Indicator & $\begin{array}{c}\text { Loading } \\
\text { Factor }\end{array}$ & Conclusion \\
\hline \multirow{3}{*}{ JE } & X1 & .85 & Valid \\
& X2 & .88 & Valid \\
& X3 & .67 & Valid \\
& X4 & .68 & Valid \\
JS & X5 & .84 & Valid \\
& X6 & .83 & Valid \\
& X7 & .59 & Valid \\
PG & X8 & .73 & Valid \\
& X9 & .79 & Valid \\
& X10 & .67 & Valid \\
WS & X11 & .85 & Valid \\
& X12 & .93 & Valid \\
& X13 & .86 & Valid \\
JEN & X14 & .85 & Valid \\
& X15 & .80 & Valid \\
& X16 & .65 & Valid \\
CC & X17 & .74 & Valid \\
& X18 & .78 & Valid \\
\hline
\end{tabular}

\section{Goodness of Fit (GOF) Test}

Structural model analysis in SEM begins with testing the suitability of the overall model which is seen based on the Goodness-of-Fit Index (GFI) indicator of LISREL output (Hair, Black, Babin, Anderson \& Tatham, 2006). Overall, a summary of the critical values from the model compatibility test can be shown in Table 3 .
The model match test results show that RMSEA is smaller than .08; therefore, it is said to be a good fit model. In addition, the results of testing CFI, IFI, NFI, RFI, GFI, and AGFI meet the suitability of the model in which each value is greater than .90 showing data good fit.

\section{Structural Model Results}

The results of processing questionnaire answers to honorarium teacher samples can be seen in structural equation modeling (SEM) as Figure 2 and 3.

Hypothesis tests are conducted by examining at the critical value (CR) at a 95\% confidence level or a $5 \%$ error. Table 4 shows five hypotheses are accepted by obtaining a value of $\mathrm{t}$ which is greater than 1.96.

Table 4 shows that Job Expectation (JE), Job Satisfaction (JS), and Government Policy (PG) variables have a significant influence on Work Stress (WW) with the highest JE loading value. WW variables have an influence on Job Enthusiasm (JEn) and Continuance Commitment (CC) variables.

\section{Test Results Relationships between Latent Variables}

While the above analyses describe the relationship to the outcome variables. Each indicator in this study also contributes to exogenous and endogenous variables. To estimate the results, the relationship between variables and indicators can be seen from the coefficient values in the model. The factor load coefficient or high coefficient is an evident that the measured variable or factor represents the underlying construction. Table 5 shows the relationship between variables and indicator variables.

Table 3. GOF Test Results Study of Honorarium Teacher

\begin{tabular}{lccc}
\hline \multicolumn{1}{c}{ Size Degree of Match } & Value & $\begin{array}{c}\text { Acceptable level of } \\
\text { compatibility }\end{array}$ & Conclusion \\
\hline Goodness of Fit Indices (GFI) & .91 & GFI $\geq .9$ & Good Fit \\
Root Mean Square Error of Approximation (RMSEA) & .068 & RMSEA $\leq .08$ & Good Fit \\
Normed Fit Index (NFI) & .94 & NFI $>.90$ & Good Fit \\
Adjusted GFI (AGFI) & .95 & AGFI $\geq .09$ & Good Fit \\
Comparative Fit Index (CFI) & .97 & CFI $>.90$ & Good Fit \\
Incremental Fit Index (IFI) & .97 & IFI $>.90$ & Good Fit \\
Relative Fit Index (RFI) & .93 & RFI $>.90$ & Good Fit \\
\hline
\end{tabular}


Standardized Solution

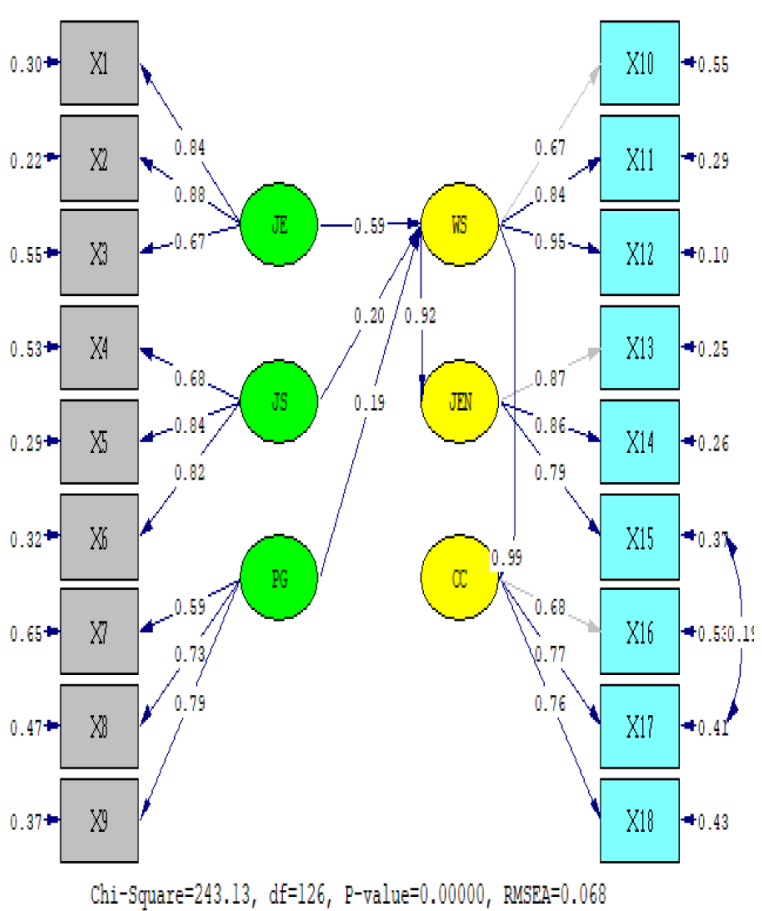

T-Value

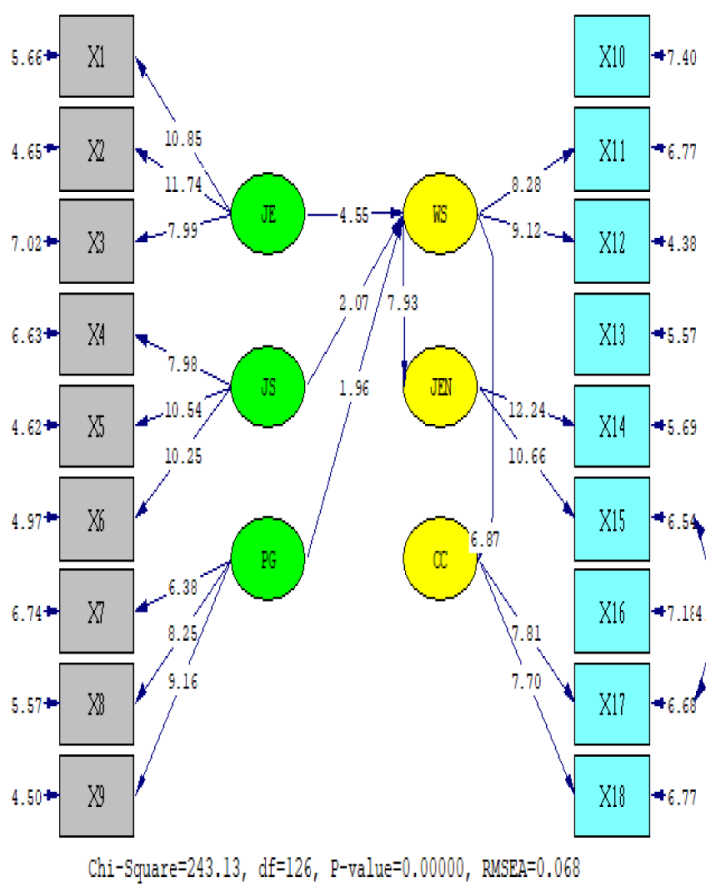

Figure 2 and 3. Standardized Solution Results and T. Value Teacher Study Honorarium

Table 4. Test Results Hypothesis Study of Honorarium Teacher

\begin{tabular}{clccc}
\hline No. & \multicolumn{1}{c}{ Hypothesis } & Loading & T-Value & Conclusion \\
\hline 1. & Job Expectation (JE) towards Work Stress (WS) & .59 & 4.55 & Hypothesis is accepted \\
2. & Job Satisfaction (JS) towards Work Stress (WS) & .20 & 2.07 & Hypothesis is accepted \\
3. & Government policy (PG) towards Work Stress (WS) & .19 & 1.96 & Hypothesis is accepted \\
4. & Work Stress (WS) towards Job Enthusiasm (JEn) & .92 & 7.93 & Hypothesis is accepted \\
5. & Work Stress (WS) towards Continuance Commitment (CC) & .99 & 6.87 & Hypothesis is accepted \\
\hline
\end{tabular}

Table 5. Test Results of Exogenous Variable Indicator Relationships with Endogenous Variables Study of Honorarium Teacher

\begin{tabular}{|c|c|c|c|c|}
\hline Variables & Indicators & $\begin{array}{l}\text { Loading } \\
\text { Value }\end{array}$ & $\begin{array}{l}\text { Construct } \\
\text { Coefficient }\end{array}$ & $\begin{array}{l}\text { Contribu- } \\
\text { tion }\end{array}$ \\
\hline Job Expectation (JE) & $\begin{aligned} X_{1}= & \text { Life improvement } \\
X_{2}= & \text { Become a state civil } \\
& \text { apparatus (PNS/ASN) } \\
X_{3}= & \text { Future goals }\end{aligned}$ & $\begin{array}{l}.59 \\
.59 \\
.59\end{array}$ & $\begin{array}{l}.84 \\
.88 \\
.67\end{array}$ & $\begin{array}{l}.4956 \\
.5192 \\
.3953\end{array}$ \\
\hline Job Satisfaction (JS) & $\begin{array}{l}X_{4}=\text { Sense of equality } \\
X_{5}=\text { Income } \\
X_{6}=\text { Working conditions }\end{array}$ & $\begin{array}{l}.20 \\
.20 \\
.20\end{array}$ & $\begin{array}{l}.68 \\
.84 \\
.82\end{array}$ & $\begin{array}{l}.1360 \\
.1680 \\
.1640\end{array}$ \\
\hline Policy Government (PG) & $\begin{array}{l}X_{7}=\text { Education certificate } \\
X_{8}=\text { Recruitment moratorium } \\
X_{9}=\text { Work agreement system }\end{array}$ & $\begin{array}{l}.19 \\
.19 \\
.19\end{array}$ & $\begin{array}{l}.59 \\
.73 \\
.79\end{array}$ & $\begin{array}{l}.1121 \\
.1387 \\
.1501\end{array}$ \\
\hline Job Enthusiasm (JEn) & $\begin{array}{l}X_{10}=\text { Work motivation } \\
X_{11}=\text { Work performance } \\
X_{12}=\text { Work time management }\end{array}$ & $\begin{array}{l}.92 \\
.92 \\
.92\end{array}$ & $\begin{array}{l}.87 \\
.86 \\
.79\end{array}$ & $\begin{array}{l}.8004 \\
.7912 \\
.7268\end{array}$ \\
\hline $\begin{array}{l}\text { Continuance Commitment } \\
\text { (CC) }\end{array}$ & $\begin{array}{l}X_{13}=\text { dependence on work } \\
X_{14}=\text { Work loyalty } \\
X_{15}=\text { Continuation of work }\end{array}$ & $\begin{array}{l}.99 \\
.99 \\
.99\end{array}$ & $\begin{array}{l}.68 \\
.77 \\
.76 \\
\end{array}$ & $\begin{array}{l}.6732 \\
.7263 \\
.7524 \\
\end{array}$ \\
\hline
\end{tabular}




\section{Discussion}

\section{Job Expectation towards Work Stress}

Khairunnisa (2015) suggests that someone who enters the workforce supports a number of expectations, both to fulfill interests, to use abilities, to achieve an increase in life, or others. Assessment of fulfilling expectations often motivates someone to work diligently or vice versa.

The status of honorary teachers is often motivated by hopes of working as a permanent teacher. Some honorary teachers say that being a teacher is a goal of life for a long time, but others say it is driven by the desire to become permanent teachers and be accepted as a government civil apparatus (ASN). This is also supported by the opinion that working as a teacher will bring increased life, especially after the regulation requires that teachers (permanent $\mathrm{ASN}$ and Foundation status) take a competency test (Law No. 14/2005). Teachers who pass the assessment are entitled to educator certificates and teacher professional allowances and are expected to improve the welfare of teachers and families. In fact, the application of teacher professional allowances has attracted university graduates to work in the teaching profession as the main job.

Data shows that being an ASN employee is an indicator that contributes the highest value (.5192) from work expectation variables (JE), followed by indicators to improve life welfare (.4956) and indicators for dreaming to work as a teacher (.3953). Subiyanto (2002) argues, currently teachers are a profession that is quite attractive and promising for university graduates. Rumtini (2014) shows, there is an increase in the quantity and quality of the interest in the teaching profession, especially students education. In terms of quantity, there has been a sharp increase in the number of education registrants, especially elementary school teacher education study programs. On the quality side, there was a better increase in ranking when in high school in some of the early semester students compared to the final semester students, although the majority of education students still came from those who had lower ranks when in high school.

Factual conditions that are not conducive and do not meet work expectations, especially the delay in the recruitment of ASN employees by the government for 10 years, have caused uncertainty to make it happen. The impact is the significant influence between work expectations and work stress situations on honorary teachers, even workloads that are considered heavy and low income, and work relationships that are considered to lack respect for the existence of honorary teachers. As teachers with honorary status, they do not have the right to take competency tests to get educator certificates and teacher professional allowances from the government.

\section{Job Expectation towards Work Stress}

At least, there are three important indicators in checking employee job satisfaction in the workplace, namely: a sense of equality, income level, and work environment. The conditions of the three indicators can bring job satisfaction, and vice versa. In the context of honorary teachers, the environment of equality (and justice), and adequate income will directly direct teacher satisfaction with work. Conversely, a work environment that does not support work activities, low income, and inequality will tend to shape the conditions of teacher job dissatisfaction.

Data shows that the indicators that provide the highest value for the variable job satisfaction are income levels (.1680), work environment (.1640), and a sense of equality of treatment (.1360). Various studies do show that there is a relationship between the level of income and employee job satisfaction. Judge, Piccolo, Podsakoff, Shaw, \& Rich (2010) suggested the influence of income level on employee job satisfaction. The same was stated by Salisu, Ezekiel, \& Subashini (2015); Mabaso \& Dlamini (2017); Rozzaid, Toni, \& Anggun (2015) the effect of significant income levels on employee job satisfaction. On the other hand, Wibowo, Mochammad, \& Gunawan (2014); Azhar \& Rasto (2018); Rohim (2018) showed a significant influence between the work environment and employee job satisfaction. In terms of relations between employees, Dahl \& Lorentzen (2003) suggests that the treatment of equality in social relations in the workplace represents one aspect that can provide employee job satisfaction. Ahmad \& Hermawan (2012) suggest that employee communication is the most dominant component of employee relations affect employee job satisfaction. 


\section{Government Policy towards Work Stress}

Teachers in Indonesia from elementary and secondary school levels have long noted the number of shortcomings. Efforts to overcome teacher shortages are done by recruiting teachers which are paid based on the number of teaching hours. In the past, schools were allowed to withdraw funds from parents for school registration fees (often referred to as school development fees) and student education costs each month. Starting in 2012, after the completion of the nine-year compulsory education program (elementary and junior high school), the Minister of Education and Culture No. 44/2012 was issued as a revision of Minister of National Education Regulation No. 60/2011 on the prohibition of schools (elementary and junior high school) to collect education funds from parents of the students. For education costs, the government implemented a school operational assistance program (known as BOS).

Since the Regulation No. 44/2102 was issued, salary for the honorarium teachers is provided through the provision of school operational assistance funds (BOS) or special allocation funds (DAK). However, since 2018, the honorarium teachers have been threatened after the issuance of Government Regulation No. 49/2018 on Management of Government Employees with Employment Agreements (known as PPPK). In this regulation, schools may not recruit the honorarium teacher, but with a minimum one-year contract. The Minister of Education and the Culture of the Republic of Indonesia also emphasized the school's prohibition on recruiting the honorarium teachers. Recruitment of teachers with employment agreements will be implemented objectively through selection of competencies, qualifications, and other requirements.

Implicitly, government policy prohibits honorary teacher status from competency testing, several years of ASN teacher recruitment moratorium, and the issuance of Government Regulation No.49/2018 regarding the recruitment of teachers with work agreements (contracts), has a significant influence on the conditions of work stress. Among these indicators, the regulations on employment agreements accounted for the highest value (.1501), followed by the ASN recruitment moratorium (.1387), and competency tests (.1121). Government Regulation No.
$49 / 2018$ is considered to cover the possibility of honorary teachers becoming permanent ASN teachers. Tabouli, Habtoor, \& Disomimba (2016); Sapitri (2016); Jianglin \& Xiuting (2018) indirectly show how organizational commitment to issued policies has an influence on employee performance.

\section{Work Stress towards Job Enthusiasm}

Job expectations (JE), job satisfaction (JS), and government policy (PG) are exogenous variables that influence endogenous work stress variables (WS). WS is also an exogenous variable has effect on endogenous variables, namely work enthusiasm (JEn). This means that work stress conditions on honorary teachers affect work enthusiasm. This influence can be reversed: if high levels of work stress will affect the realization of low work enthusiasm; on the contrary, if the work stress level is low, work enthusiasm tends to be high. Experts argue, work stress is one of the human sub-aspects that affect organizational commitment, especially work enthusiasm. The stress experienced by employees in the workplace is often seen as a negative situation for the development of the company, especially productivity which tends to stagnate and even decline. One cause is low employee enthusiasm (Lambert, Nancy, \& Marrie, 2007; Khatibi, Asadi, \& Hamidi, 2009; Masihabadi, Rajaei, Koloukhi, \& Parsian, 2015; Velnampy \& Aravinthan, 2013; Tahir, 2010).

There are at least three indicators (motivation, achievement, and time management) that contribute to the condition of work enthusiasm. The results of show data analysis work motivation is an indicator that contributes the highest value (08004) to work enthusiasm, followed by performance $(.7912)$ and time management (.7268). That is, the honorarium of teachers who suffer from work stresses tend to realize work motivation and performance, and unplanned, undisciplined and ineffective time management. Various studies generally show a significant influence between work motivation on employee performance, as done by Ali, Bin, Piang, \& Ali (2016); Maduka \& Okafor (2014); Larasati \& Arini (2014); Ady \& Wijono (2013), then influence work enthusiasm employee. High work motivation influences determining performance and high 
work enthusiasm, ultimately tends to produce high work productivity, and vice versa.

\section{Work Stress towards Continuance Commitment}

The exogenous work stress (WS) variable has been shown to have an influence on the endogenous variable, Continuance Commitment (CC). Various studies have indeed shown a strong influence between WSs on the sustainability commitment of employees in the workplace. Khatibi, et. al. (2009); Dewi \& Wibawa (2016); Gumilang \& Baidun (2014); Rawal \& Mhatre (2018) showed an influence between work stress and employee turnover. High work pressure will affect employees looking for new workplaces, whereas workplaces that are less felt to burden employees will bring impunity. Variable Continuance Commitment is at least three indicators, namely: dependence on work, loyalty, and sustainability. It was found that the loyalty indicator contributes to the highest value for the $\mathrm{CC}$ variable (.7524), followed by work continuity (.7263), and work dependence (.6732).

It means that work stress of the honorarium teachers lead to a condition of low work loyalty, where the teacher does not have a strong sense of belonging to the school. Teaching activities tend to be done half-heartedly, without integrity and responsibility for achieving quality results. The perceived heavy burden of work, with low income levels, hopes of becoming a permanent teacher who disappeared, and uncertainty about the status of work going forward, stimulated themselves to look for a new better workplace. The honorarium teacher tends to no longer rely on his hopes and work as a teacher, and at any time can move to a new place. This indication can be seen from the phenomenon of the resignation of honorarium teachers from schools.

\section{CONCLUSION}

Attention to honorarium teachers shows that variables influence their work stress conditions, and further affect job enthusiasm and continuance commitment. The small expectations of becoming a teacher with an ASN status tend to show less passionate work situations and encourage them to move if they get a new better workplace. This indication has been seen from the actions of a number of honorarium teachers who resigned and tended to be followed by other teachers. The resignation of the honorarium teacher is predicted to interfere the school learning activities, and losses for students. Therefore, it is necessary to respond and find a solution so that teaching and learning activities can run normally.

The implementation of employee recruitment (including teachers) based on the Government Regulation no. 49/2018 with a system of employee agreements (contracts) needs to be reviewed. Teacher's recruitment needs to give priority to the teachers who have received honorarium status, without going through a selection test, but must obtain competency improvement training. Afterwards, it is also required to undergo a probationary period (not a contract) for a certain period of time (for example: one year). The assessment process is carried out to determine the eligibility to be accepted as a non-ASN Permanent Teacher. The salary for this employment is based on the regional (provincial/district) minimum wages. In addition, non-ASN Permanent teachers are entitled to take competency tests by the government and obtain teacher professional allowances, entitled to participate in Continuing Professional Development (CPD) training, are entitled to participate in the activities of teacher professional organizations, obtain family health services, and leave rights. In certain cases, such as placement in remote areas, inland areas and borders between countries, this type of teacher has the right to receive special benefits in accordance with applicable regulations.

\section{REFERENCES}

Ady, F., \& Wijono, D. (2013). Pengaruh motivasi kerja terhadap kinerja karyawan. MAKSIPRENEUR Journal, 2(2), 101-112. doi:10.30588/jmp.v2i2.278.

Ahmad, N., \& Hermawan, D. (2012). Analisis pengaruh hubungan karyawan (employee relation) terhadap kepuasan kerja karyawan PT. Menara Kartika Buana di Karanganyar. BENEFIT Jurnal Manajemen dan Bisnis, 16(2), 106-115. doi:10.23917/benefit.v16i2.1360.

Ali, A., Bin, L. Z., Piang, H. J. \& Ali, Z. (2016). The impact of motivation on employee 
performance and job satisfaction in IT park (software house) Sector of Peshawar, Pakistan. International Journal of Academic Research in Business and Social Sciences, 6(9), 297-310. doi:10.6007/ IJARBSS $/ v 6-i 9 / 2311$.

Asnawi, S., \& Bachroni, M. (1999). Keterlibatan pelaksanaan tugas dengan disiplin terhadap peraturan kesehatan dan keselamatan kerja. Jurnal Psikologi, 26(2), 78-85. doi:10.22146/jpsi.6991.

Azhar, M. N., \& Rasto, $R$ (2018). Lingkungan kerja dan implikasinya terhadap kepuasan kerja karyawan. Jurnal Pendidikan Managemen Perkantoran, 3(2), 123-126. doi:10.17509/jpm.v3i2.11816.

Bakan, I., Buyukbese, T., Er ${ }^{\circ} a h a n$, B., \& Sezer, B. (2014). Effects of job satisfaction on job performance and occupational commitment. International Journal of Management \& Information Technology, $9(1), \quad 1472-1480$. doi:10.24297/ijmit. v9i1.668.

Bawelle, M., \& Sepang, J. (2016). Pengaruh etos kerja ,gairah kerja dan disiplin kerja terhadap kinerja karyawan PT. BRI cabang Tahuna. Jurnal EMBA, 4(5), 303-408.

Colquitt, J. A., Jeffery, A. L., \& Michael J. W (2015). Organizational behavior improving performance and commitment in the workplace. New York, NY: McGraw Hill.

Darmawati, A., Hidayati, L. N., \& Dyna, H. S. (2013). Effect of job satisfaction and organizational commitment on organizational citizenship behavior. Jurnal Economia, 9(1), 10-17. doi:10.21831/ economia.v9i1.1372.

Dewi, K. A. B. P., \& Wibawa, I. M. A. (2016). Pengaruh stres kerja pada turnover intention yang dimediasi kepuasan kerja agen AJB Bumiputera 1912. Jurnal Manajemen, 5(6), 3560-3588.
Dahl, E. \& Lorentzen, T. (2003). Dynamics of social assistance: The Norwegian experience in comparative perspective. International Journal of Social Welfare, 12(4), 289-301. doi:10.1111/14679671.00283 .

Greenberg, J., \& Baron, R. A. (2003). Behavior in organization. New Jersey, NJ: Prentice Hall.

Greenhaus, J. H., Seidel, C., \& Marinis, M. (1983). The impact of expectations and values on job attitudes. Organizational Behavior and Human Performance, 394417. doi:10.1016/0030-5073(83)90132-0.

Gumilang, M. N. K, \& Baidun, A. (2014). Pengaruh kepuasan kerja dan stres kerja terhadap intensi turnover. TAZKIYA Journal of Psychology, 2(2), 265-281. doi:10.15408/tazkiya.v4i1.10831.

Hair, J. F. Jr., Black, W. C., Babin, B. J., Anderson R. E., \& Tatham, R. L. (2006). Multivariate data analysis (6th Ed.). Upper Saddle River, NJ: Prentice Education, Inc.

Handayani, R. D. (2016). Effect of environment and work spirit on civil servant performance Balitsa Lembang. Journal of Tourism, 2(1), 40-51. doi:10.31311/ par. v2i1.352.

Herjany, E., \& Bernarto, I. (2018). Effect of work environment, job satisfaction, and work stress on organizational commitment of kindergarten and elementary teachers at school X in West Jakarta. Indonesian Management Journal, 18(2), 154-164.

Hidayat, A. S. (2018). Pengaruh kepuasan kerja terhadap komitmen organisasi dan turnover intention. Jurnal Manajemen dan Pemasaran Jasa, 11(1), 51-66. doi:10.25105/jmpj.v10i1.2516.

Jazak, Y. A. (2015, February). Stres, karyawan, dan perusahaan. Retrieved from https://ekonomi.kompas.com/ $\mathrm{read} / 2015 / 02 / 16 / 070700526 / . \% 20$ Stres. Karyawan.dan.Perusahaan. 
Judge, T.A., Piccolo, R. F., Podsakoff, N. P., Shaw, J. C., \& Rich, B. L. (2010). The relationship between pay and job satisfaction: A meta-analysis of the literature. Journal of Vocational Behavior, 77(2), 157-167. doi:10.1016/j.jvb.2010.04.002.

Jianglin,K.\& Xiuting,D.(2018). Family-friendly human resource practice, organizational commitment, and job performance among employees: The mediating role of workplace spirituality. Journal of Human Resource and Sustainability Studies, 6(1), 81-91. doi:10.4236/jhrss.2018.61028.

Khairunnisa, A. (2015, September). Hubungan antara kepuasan dan komitmen kerja karyawan dengan intensi turnover pada perusahaan. Retrieved from https:// psychology.binus.ac.id/2015/09/21/ hubungan-antara-kepuasan-dankomitmen-kerja-karyawan-denganintensi-turnover-pada-perusahaan/.

Khatibi, A., Asadi, H., \& Hamidi, M. (2009). The relationship between job stress and organizational commitment in National Olympic and Paralympic Academy. World Journal of Sport Sciences, 2(4), 272-278.

Kirkpatrick, T. O., \& Levis, C. T. (1995). Effective supervision. New York, NY: The Bryden Press.

Koran Sindo. (2018, September). Pengadaan guru honorer dilarang. Retrieved from: http://koran-sindo.com/page/news/201809-24/0/24/Pengadaan_Guru_Honorer_ Dilara ng.

Krissandi, S. A. D., \& Rusmawan, (2015). Constraints of primary school teachers in implementing 2013 Curriculum. Education Horizon Journal, 34(3), 457467. doi:10.21831/ cp.v3i3.7409.

Kusluvan, S (2003). Managing employee attitudes and behavior in the tourism and hospitality industry. New York, NY: Nova Science Publishers, Inc.
Kusnendi, (2008). Model-model persamaan struktural: Satu dan multigroup sampel dengan LISREL. Bandung: Alfabeta.

Lambert, E. F., Nancy, L. H., \& Marrie, L. G. (2007). The impact of distributive and procedural justice on correctional staff job stress, job satisfaction, and organizational commitment. Journal of Criminal Justice, 35(6), 644-656. doi:10.1016/j. jcrimjus.2007.09.001.

Larasati, S., \& Arini, G. (2014). The influence of work motivation on the employees' performance in the North West West Telkom Region (Witel Bekasi). Journal of Management and Organization, 5(3), 200-213.

Latan, H. (2012). Structural equation modeling konsep dan aplikasi menggunakan LISREL 8.80. Bandung: Alfabeta.

Luthans, F. (2011). Organizational behavior. New York, NY: McGraw-Hill.

Mabaso, C. M., \& Dlamini, B. I. (2017). Impact of compensation and benefits on job satisfaction. Research Journal of Business Management, 11(2), 80-90. doi:10.3923/ rjbm.2017.80.90.

Maduka, C. E., \& Okafor, O. (2014). Effect of motivation on employee productivity: A study of manufacturing companies in Nnewi. International Journal of Managerial Studies and Research (IJMSR), 2(7), 137-147.

Masihabadi, A., Rajaei, A., Koloukhi, A. S., \& Parsian, H. (2015). Effects of stresss on auditor organizational commitment, job satisfaction, and job performance, International Journal of Organizational Leadership, 4(2015), 303-314.

Mulia, W. (2013). Pengaruh kepuasan kerja dan motivasi terhadap kinerja karyawan Giant Supermarket Cabang Manggarai. Jurnal MIX, 3(2), 175-188. 
Mullins, L. J (2007). Management and organizational behavior. London: Pearson Education Prentice Hall.

Mulyasa, E. (2006). Menjadi guru profesional menciptakan pembelajaran kreatif dan menyenangkan. Bandung: Remaja Rosdakarya.

Nitisemito, A. S. (1992). Human resources management. Yogyakarta: UGM BPFE.

Noviyanti, R., \& Erwandi, D. (2012). Analisis faktor yang terkait dengan pekerjaan stres untuk guru honorer sekolah menengah di Jakarta Timur. Retrieved from http://lib.ui.ac.id/bo/uibo/detail. jsp?id=20331705\&lokasi=lokal.

Orpen, C. (1974). The effect of expectations on managerial job performance: A four-year longitudinal study with South African business managers. The Journal of Social Psychology, 93(1), 135-136. doi:10.1080/ 00224545.1974 .9923138 .

Ratnasari, D. (2015). Effect of expectation levels and service performance on community satisfaction levels through confirmation as intervening variables (Study on Surabaya municipality population and civil registry service). Public Policy and Management, 3(1), 1-12.

Rawal, A., \& Mhatre, S. (2018). A study on work stress and its impacts on employee productivity with respect to teacher (selffinancing). IOSR Journal of Business and Management (IOSR-JBM), 15-23.

RoI, Goverment Regulation 2018 No. 49, Management of Employee Governments with Employment Agreements (PPPK).

RoI, Law 2005 No. 14, Lecturers and Teachers.

RoI, Ministrial Regulation of National Education 2011 No. 60, Prohibition of Collection of Education Fees in Primary and Secondary Schools.
RoI, Ministrial Regulation of Education and Culture 2012 No. 44, Charges and Contributions to Education Costs in Basic Education Units.

Rizkiyani, D., \& Saragih, S. (2012). Work stress and work motivation on prison workers. Journal of Management, 12(1), 27-44.

Rohim, A. (2018). Effect of work environment on employee job satisfaction. Journal of Economics and Business, 20(2), 106-119.

Rozzaid, Y., Toni, H., \& Anggun, M. D. (2015). Effects of compensation and motivation on employee job satisfaction (Case Study at PT Nusapro Telemedia Persada Banyuwangi Branch). Journal of Indonesian Business and Management, 1(2), 201-220.

Rumtini. (2014). Impact evaluation of the teacher living standard improvement on input quality enrollment. Journal of Education and Culture, 20(2), 211-222.

Salisu, J. B., Ezekiel. C. \& Subashini, S (2015). The impact of compensation on the job satisfaction of public sector construction workers of Jigawa State of Nigeria. The Business and Management Review, 6(4), 282-296.

Sapitri, R. (2016). Effect of organizational commitment on employee performance of pekanbaru state electricity company. JOM Fisip, 3(2), 1-9.

Shaju, M., \& Subhashini, D. (2017). A study on the impact of Job Satisfaction on job performance of employees working in automobile industry, Punjab, India. Journal of Management Research, 9(1), 117-130. doi:10.5296/jmr.v9i1.10420.

Sinwan, M. (2014). Faktor-faktor penghambat pelaksanaan kurikulum 2013 (Studi deskriptif di SMA Negeri 1 Gebog Kudus Tahun Ajaran 2013/2014). Under Graduates thesis, Universitas Negeri Semarang. 
Sjahruddin, H. (2017). Struktur kecerdasan emosional, kecerdasan spiritual, dan hubungannya dengan antusiasme kerja dan kinerja auditor. Jurnal Bisnis dan Manajemen, 3(1), 67-85.

Subiyanto, S. (2002). Profesi guru sebagai profesi menjanjikan pasca undang-undang dosen dan guru. Jurnal Pendidikan dan Kebudayaan, No. 067, Th. 13, 696-718.

Sukadiyanto, S. (2010). Stress dan cara menguranginya. Cakrawala Pendidikan, 29(1), 55-66. doi:10.21831/cp.v1i1.218.

Suparlan, S. (2018). Menjadi guru efektif. Bandung: Penerbit Hikayat.

Tabouli, E. M. A., Habtoor, N. A., \& Disomimba, M. N. S. (2017). The impact of human resources management on employee performance organizational commitment mediator variable. Asian Social Science, 12(9), 176-192. doi:10.5539/ass. v12n9p176.

Tahir, S. (2010). The impacts of employee job stress on organizational commitment. European Journal of Social Sciences, 13(4), 617-622.
Vecchio, R. P. (1995). Organizational behavior. Florida: The Dryden Press.

Velnampy, T. \& Aravinthan, S. A (2013). Occupational stresss and organizational commitment in private banks: A Sri Lankan experience. European Journal of Business and Management, 5(7), 254267.

Vroom, V. H. (1964). Work and motivation. New York, NY: John Wiley \& Son, Inc.

Werang, B. R. (2014). Pengaruh kepemimpinan transformasional kepala sekolah, moral kerja guru, dan kepuasan kerja terhadap kinerja guru SDN di Kota Merauke. Cakrawala Pendidikan, 33(1), 128-137. doi:10.21831/cp.v1i1.1869.

Wibowo, W. (2007). Manajemen kinerja. Jakarta: Raja Grafindo.

Wibowo, M., Mochammad, A. M., \& Gunawan, E. N. (2014). Pengaruh Lingkungan Kerja Terhadap Kepuasan Kerja Karyawan (Studi pada Karyawan PT. Telekomunikasi Indonesia Tbk. Kandatel Malang). Jurnal Administrasi Bisnis, 16(1), 1-9. 